\title{
FREE, PRIOR AND INFORMED CONSENT IN FULFILLING THE CONSTITUTIONAL RIGHTS OF CITIZENS IN THE MINING SECTOR
}

\author{
${ }^{[1]}$ Harliansyah; ${ }^{[2]}$ Astiti Swanita Rini; ${ }^{[3]}$ Eva Nopitasari Siagian; \\ ${ }^{[4]}$ Tuntas Karawahno Andjab; ${ }^{[5]}$ Rokhaya Fall \\ ${ }^{[1-4]}$ Master of Law, Faculty of Law, Lambung Mangkurat University \\ Jl.Brigjen Hasan Basry, Kota Banjarmasin (70123) - INDONESIA \\ [5] Juriste Environnementaliste, chargée de projet à ACTION SOLIDAIRE INTERNATIONAL \\ 54, rue Carnot; Dakar (3370) - SENEGAL \\ Email: falrokhaya@gmail.com
}

Citation: Harliansyah, et.al. 2021. Free, Prior And Informed Consent In Fulfilling The Constitutional Rights Of Citizens In The Mining Sector. Int' Journal of Law, Environment, and Natural Resources (INJURLENS), 1(1), April, 11-21

Academic Editor: Ifrani Received: 10 January 2021 Revised: 23 February 2021

Accepted: 5 March 2021

Published: 12 March 2021

Publisher's Note: Scholar Center stays neutral with regard to jurisdictional claims in published maps and institutional affiliations.

\section{(c) () (-)}

Copyright:

(c) 2021 by the authors. Submitted for open access publication in International Journal of Law, Environment, and Natural Resources (INJURLENS) under the terms and conditions of the Creative Commons AttributionNonCommercial-ShareAlike 4.0 license (CC BY NC SA 4.0). For more information visit (http://creativecommons.org).

\begin{abstract}
Based on data from the Directorate General of Mineral and Coal, Ministry of Energy and Mineral Resources, in 2017, there are 9,353 Mining Business Licenses (MBL) with 9,074 MBLs entered in the DG of Mineral and Coal database. Of these, 6,565 MBLs passed the $\mathrm{CnC}$ requirements, while the remaining 2,509 MBLs were categorized as non-CnC. The focus of the problems studied are: (1) What is the Direction of Changes in Government Policy in the Mining Sector? (2) What is the relationship between Free, Prior and Informed Consent with the fulfillment of the constitutional rights of citizens in the mining sector? The method used in this study is doctrinal legal research focusing on sources of law. The result shows that (1) There are changes in government policy in the mining sector, which was only constrained in its implementation, but has now become more problematic because of the removal of the article on the imperative community participation; (2) In every policy setting, FPIC must be implemented and must be given to the community, especially those who are directly affected. Thus, FPIC can be said to be a form of community rights that must be fulfilled by the government as the licensor legally to fulfill the constitutional rights of its citizens.
\end{abstract}

Keywords: FPIC; Mining; Law; Constitution; Government.

\section{INTRODUCTION}

One of the goals of establishing a state is to create welfare and prosperity for the people, this has been included in the fourth paragraph of the Preamble to the 1945 Constitution of the Republic of Indonesia (UUD 1945). As a form of legitimacy for all actions, as well as relations between state institutions and other state institutions and/or state institutions with citizens under their respective powers, the 1945 Constitution of the Republic of Indonesia was formed as the highest source of law and is fundamental because it is the basis of an authorization of other statutory regulations. 
In the journey of Indonesia nation, many public policies issued by the government, especially in the environmental sector which have an impact on the Indonesian economy. According to the constitution, public welfare can be achieved if Article 33 paragraph (4), namely "The national economy is organized based on economic democracy with the principles of togetherness, the efficiency of justice, sustainability, environmentally friendly by maintaining a balance of progress and national economic unity" is implemented, which of course requires regulations to accommodate it, considering that the Republic of Indonesia (NKRI) is a Constitutional State under Article 1 paragraph (3) of the 1945 Constitution of the Republic of Indonesia (Huda, 2012: 201). Thus, if the two are linked, it confirms that Indonesia is a Constitutional State as well as a Social Welfare State which is none other than a Constitutional State with social justice or the Constitutional State of Social Justice which guarantees and protects the welfare rights of its citizens (Asshiddiqie, 2018: 138).

One of the methods that the government takes to achieve the aforementioned purpose is by utilizing natural resources or the environment as has been emphasized in Article 33 paragraph (3) of the 1945 Constitution of the Republic of Indonesia, namely "Earth and Water and the natural resources contained therein are controlled by the state. and used for the greatest prosperity of the people". The environment is a medium, which is all objects, energy, conditions, and living things in the universe. This includes humans and their behavior that affect nature itself, so it needs to be protected from excessive users of various parties who have also been accommodated in Article 28H paragraph (1) of the 1945 NKRI Constitution (Joni, 2015: 1).

Then, to fulfill this, the government made Legislation Number 32 of 2009 concerning Environmental Protection and Management (which was later called the EPM Act). The EPM Act aims to protect the NKRI area from pollution and environmental damage. In addition, to ensure the safety, health and life of humans, maintain environmental sustainability, harmony and balance, control the wise use of natural resources, and realize sustainable development to ensure the fulfillment of justice for present and future generations to fulfill and protect rights of the environment as part of the constitutional rights of citizens which can be achieved following Article $28 \mathrm{H}$ paragraph (1) of the 1945 Constitution of the Republic of Indonesia.

Environmental management has a relationship with various fields of human life. This relationship exists in the fields of industry, forestry, mining, agriculture, fisheries, maritime affairs, and others which are reflected in Article 36 paragraph (1) of the EPM Act which reads "every business and/or activity that is obliged to have Environment Impact Analysis or Environment Management Efforts and Environment Monitoring Efforts is obliged to have an environmental permit. " From this description it can be concluded that the relationship between the various fields mentioned above and the environment exists in terms of business licensing. This means that the EPM Act becomes the legal umbrella or umbrella act or kaderwet for other statutory regulations.

The role of the environment as an asset of the nation and the state is very important, so it requires a wise approach in its management. This wise approach to environmental management is also related because the environment is in direct contact 
with development activities. Therefore, every plan and/or activity that can affect the environment hugely is required to have an analysis of environmental impacts (Supriadi. 2006: 191).

Quoted from Tribunnews.com, President Jokowi said that infrastructure development will continue on a large scale and will make it faster and connect the infrastructure with rice fields, plantation areas and fishery ponds. This is an innovation or a new method that will be carried out during his reign in the hope that job fields will be opened as much as possible, so according to him, it is necessary to abandon the old methods that hinder investment.

The speech received huge criticism from Walhi because the government's efforts to re-realize the spirit of bureaucratic reform by accelerating the investment licensing process is contradictory with the spirit of issuing permanent policies to save humanity, the environment and the people as promised in 2014 . This was then actually realized by the government in October 2020 with the issuance of the Omnibus Law which we will discuss further.

In retrospect, in the 2015-2019 National Mid-Term Development Plan, it was noted that during the previous administration, Jokowi-JK also developed industrial zoning, including industries based on strategic mining products, which means that mining will be stacked or concentrated in one place (BPPN, 2014: 125).

Based on the data from the Directorate General of Mineral and Coal, Ministry of Energy and Mineral Resources (ESDM), in 2017, there are 9,353 MBLs with 9,074 MBLs entered in the DG of Mineral and Coal database. Of these, 6,565 MBLs passed the CnC requirements, while the remaining 2,509 MBLs were categorized as non-CnC. Thus, the number of MBLs that are still actively conducting mining activities is 3,487 MBLs. Meanwhile, out of the MBLs with problems, 664 of them are still active in mining activities. JATAM also noted that $44 \%$ of the total area of the Indonesian oceans and archipelago has been plotted by mining which has resulted in a loss of 4.3 trillion Rupiahs from problematic MBLs.

The high losses incurred by the mining sector indicate that there has been no serious effort by the government to resolve agrarian conflicts caused by development policies and practices and the expansion of mining in Indonesia. The smooth flow of connectivity created by integrated infrastructure development and regional development is needed to boost the country's economy. However, unilateral and coercive, non-participatory, non-transparent and corrupt processes and business orientated ways that are strongly prioritized than the public interest, so the repressive approaches to the citizens' resistance are always visible in land acquisition projects for the development of the property and infrastructure industry, one of them is the mining sector (KPA, 2019: 27). Until now, after many cases in the mining sector, including land disputes, corruption, money laundering and the environment, even after the watchdoc investigative video report entitled Sexy Killer, there has been no government policy regarding mining monitoring. As the Jokowi administration progressed, the Environment Impact Analysis permit - an important thing in the use of mineral and coal natural 
resources - was removed, besides the centralization of mining permits which is not following the Regional Government Law stating that the regional government can give authority regarding the management and utilization of natural resources related to licensing authority, thus it makes the hearing with the local community becoming harder to be realized. Logically, when the permits issued by the local government often cause conflicts, it will cause more if the licenses are centralized to the central government.

This situation is contradictory with the narrative that was built that development aims to boost the economy and people's welfare through the concept of sustainable development as stated in article 1 point 3 of Legislation No. 32 of 2009 concerning Environmental Protection and Management, which states that "sustainable development is a conscious and planned effort that combines environmental aspects as well as safety, capability, welfare, and quality of life for present and future generations". Based on the description above, the authors' title this paper: "Free, Prior and Informed Consent in Fulfilling Citizens' Constitutional Rights in the Mining Sector". The focus of the problems studied are:

1. What is the direction of the changes in government policies in the mining sector?

2. What is the relationship between Free, Prior and Informed Consent with the fulfillment of the constitutional rights of citizens in the mining sector?

\section{METHODS}

In the making of scientific work, especially legal research scientific work, it is required to use legal research methods. Law studies seek to present law integrally according to the needs of the study of law itself, so that research methods are needed to obtain a comprehensive research direction (Nurhayati, 2013: 15). Legal studies have characteristics as a prescriptive and applied science. In prescriptive, legal studies study the objectives of the law, the values of justice in law, the good and bad of a rule of law, concepts, and legal norms. Whereas in applied science, legal science establishes a procedure, provisions, and limitations in enforcing a legal rule (Nurhayati, 2020: 9).

Legal research seeks to present legal developments following the needs of legal studies, however, there are dualism or dichotomy in methodology. The dichotomy of legal research methods (doctrinal and non-doctrinal) is also influenced by the development of legal philosophers' schools of thought (Nurhayati, Ifrani, Said, 2021: 125). The method used in this study is doctrinal legal research focusing on sources of law. The analysis is performed qualitatively without numbers, statistical formulas, and mathematics.

\section{RESULTS AND DISCUSSION}

\subsection{Direction of Changes in Government Policy in the Mining Sector}

To comply with Article 33 paragraph (3) and 28H paragraph (1) of the 1945 Constitution of the Republic of Indonesia, the Mineral and Coal Act requires a feasibility study prior to the issuance of Mining Business License (MBL) and Special Mining Business License (SMBL) in terms of production operations as a form of Indonesian 
economic development, based on the principles of sustainability and environmentally friendly. A feasibility study is a series of processes before production starts. In that part, there is the most important thing, namely an environmental impacts analysis which is a study of the major and important impacts of a business and/or an activity planned on the environment required for the decision-making process regarding the operation of businesses and/or activities handled by the central government and the local governments.

Article 3 paragraph (1) Government Regulation Number 27 of 2012 concerning Environmental Permits as the implementing regulation of the Mineral and Coal Law also states that "Every business and/or activity that has an important impact on the environment is required to have an Environment Impacts Analysis". However, the current government policy that prioritizes bureaucratic reform, cutting permits which are deemed to be difficult for investors, contradicts this aforementioned article, especially the Article 40 of the Job Creation Act in the Environmental Protection and Management Act regarding environmental permits which is being abolished. In addition, Article 26 Paragraph (2) of the Environmental Protection and Management Act which reads "Community involvement must be carried out based on the principle of providing transparent and complete information and notified before the activity is carried out" is abolished so that only the involvement of Environment Impacts Analysis process which is followed by the affected community, meaning that people who have felt the impact. Before that, the community should also take part in monitoring the reports of the revenue obtained by the business owner to the government in accordance with Free, Prior, Informed Consent (FPIC) regarding public openness, especially government policies that carry people's interests first. It needs to be disseminated to the public in accordance with Article 2 letter $b$ regarding the principles of transparency, participation and accountability. FPIC is discussed further in another section.

Again, Article 88 of the Environmental Protection and Management Act which is in the Job Creation Law is also deleted in the section "absolute responsibility for losses that occur without proof of the element of error". In addition, Article 79 of the Environmental Protection and Management Act regarding license suspension or revocation is also deleted in the Job Creation Law. Now logically, if in the Environmental Protection and Management Act is an umbrelact of the environment in the Job Creation Law, many important articles are deleted, then some of the articles in the Mineral and Coal Act can no longer be used.

George W. (Rock) Pring stated that there are two important developments in the mining industry and their relationship with natural resources programs by governments around the world. One is positive and the other one is problematic. The first trend is to open up international opportunities to develop mineral resources (mining materials). The second trend is emerging challenges related to mining production, products and development. It is natural that mining causes environmental, social, cultural and economic disturbances (Rock, 1999: 5). On the other hand, mining also has a negative impact on the environment. Mining is an activity with conditions with a risk of environmental pollution and/or damage, such as (Muhjad, 2015: 147): 
1. Damage to the landscape due to metal pools/holes that are not immediately reclaimed;

2. Sources of water pollution, both high turbidity levels and mercury content in gold mining by the people;

3. Causes of erosion and sedimentation as well as damaging watershed and water systems;

4. The occurrence of wasteful use of mineral resources;

5. Prone to mining accidents;

6. Threatens forest and aquatic ecosystems.

Besides that, deforestation for exploration and exploitation activities, soil excavation, noise from mining machines, air pollution by the dust from mining machine and water pollution due to disposal of mining waste into rivers or the sea are some of the adverse impacts of mining on the environment. Mining also triggers social conflicts between mining companies and communities around the mining area or between communities around the mining area.

The development of mining management without damaging the environment is part of the development without damaging the environment that has been campaigned globally by the United Nations. Environmentally based mining activities are an absolute necessity (Effendi, 2014: 127).

Therefore, the obligation to have Environmental Impact Analysis is also useful for the implementation of reclamation activities carried out throughout the mining business stages to organize, restore and improve the quality of the environment and ecosystem so it can function again according to its purpose. Reclamation is included in post-mining activities, hereinafter referred to as post-mining activities, whose activities are planned, systematic, and continuous after the end of a part or all of the mining business activities to restore natural environmental functions and social functions based on the local conditions throughout the mining area.

In addition to paying attention to environmental impacts, the Mineral and Coal Act also requires community empowerment by the government and local business license holders, as an effort to improve the capacity of the community, both individually and collectively, so that their life will be better.

Article 1 point 33 concerning state reserved areas, hereinafter referred to as SRA which is part of mining areas reserved for national strategic interests, fulfills Article 33 paragraph (4) of the 1945 NRI Constitution. Article 2: Mineral and/or coal mining is managed on the basis of: (a) Benefits, equity and balance; (b) Taking sides with the interests of the nation; (c) Participation, transparency and accountability; (d) Sustainable and environmentally sound.

In this article, the explanation for Article 2 letter $d$ stating what is meant by the principle of being sustainable and environmentally sound is part of the principle of mining which is planned to integrate economic, environmental and socio-cultural dimensions in the mineral and coal mining business in order to realize the present and 
future prosperity. It is in accordance with the mandate of the constitutional state of Pancasila, including the constitutional rights of citizens that require a balance between economy, development and the environment.

Article 142 paragraph (2) states that "The government can give a warning to the local government if in exercising its authority it is not in accordance with the provisions of this Law and the provisions of other laws and regulations". So, it can be understood that the central government does not necessarily only give authority to local governments but also conducts supervision. In accordance with the Constitutional State principle, namely the limitation of power as a part of checks and balances in an equal position and to balance and control one another. However, if now licensing process has been transferred to the central government, then the question is who will reprimand the central government in every decision it makes.

This legislation also reaffirms in Article 166 that "Any problems arising from the implementation of Mining Business License, Community Mining Permit or Special Mining Business Licenses relating to environmental impacts are resolved in accordance with the provisions of laws and regulations" which can be understood as a form of Constitutional State, this fulfills:

1. Law Supremacy: All problems are resolved by law as the supreme guide. In the perspective of the supremacy of law, in essence the real supremacy of the state is not a human being, but a constitution that reflects the highest law. Normative recognition regarding the law supremacy is recognition that is reflected in the formulation of laws and/or the constitution, while empirical recognition is recognition reflected in the behavior of the majority of the population that law is indeed "supreme". In fact, in a republic that adheres to a pure presidential system, it is the constitution that is actually more appropriate to be called the "head of state".

2. Equality before the Law: In the framework of this principle of equality, all discriminatory attitudes and actions in all their forms and manifestations are recognized as prohibited attitudes and actions, except for special and temporary actions which are called "affirmative actions" to encourage and accelerate certain community groups or certain groups of people (in this case in the mining area) to pursue progress in order to achieve the same and equal level of development as the average community group who are much more advanced. Certain community groups that can be given special treatment through affirmative actions which do not include the definition of discrimination, for example, are isolated ethnic groups or certain indigenous peoples whose conditions are underdeveloped. Meanwhile, certain groups of community members who can be given special treatment that are not discriminatory in nature, for example those in the mining environment whose access out of the village is difficult due to damaged roads (Asshiddiqie, 2011: 9).

\subsection{Free, Prior and Informed Consent in Fulfilling the Constitutional rights of Citizens in The Mining Sector}


In the context of human rights, the state is the main legal subject, because the state is the main entity responsible for protecting, upholding, and advancing the human rights of its citizens. The development of the modern state administration regarding basic rights is then outlined in the constitution which is known as constitutional rights. According to Prof. Jimly Asshiddiqie, Constitutional rights are rights guaranteed in and by the 1945 Constitution of the Republic of Indonesia. Constitutional rights are also related to state recognition of the subject of constitutional rights, namely citizens. In the case of citizens, they are native Indonesians and people of other nations who are legally legalized as citizens. This has been stated in Article 26 paragraph (1) of the 1945 Constitution of the Republic of Indonesia.

Constitutional rights can be seen as a reciprocation of constitutional obligations. A constitutional obligation is a consequence of citizens in their position as citizens in carrying out the actions required by the state. Article $28 \mathrm{H}$ paragraph (1) and Article 33 paragraph (4) of the 1945 Constitution of the Republic of Indonesia are key provisions regarding the regulation of environmental norms in the Indonesian Constitution. In succession, the two Articles read as follows:

Article $28 \mathrm{H}$ paragraph (1): Everyone has the right to live in physical and spiritual prosperity, to have a place to live, and to have a good and healthy living environment and the right to obtain health services.

Article 33 paragraph (4): The national economy shall be carried out based on economic democracy with the principles of togetherness, fair efficiency, sustainability, environmentally friendly, independence, and by maintaining a balance between progress and national economic unity.

Based on the two articles above, it is clear that the 1945 Constitution of the Republic of Indonesia has accommodated constitutional protection, both for its citizens to obtain an adequate living environment and guarantee the maintenance of a sustainable environmental order due to the negative impact of national economic activities.

This regulation implies that every citizen has the right to and obtain a constitutional guarantee to live and obtain a good and healthy living environment to grow and develop. This regulation can also be juxtaposed with Article 25 of the Universal Declaration of Human Rights (UDHR) which states, "everyone has the right to a standard of living adequate for the health and well-being of himself and of his family". Meanwhile, Article 12 paragraph (1) of the ICESCR emphasizes, "The States Parties to the present Covenant recognize the right of everyone to the enjoyment of the highest attainable standard of physical and mental health". This means that the life needs of Indonesian citizens must also be fulfilled following adequate measures both for their health and other matters related to supporting one's life. More broadly, the meaning of this norm is strengthened by the inclusion of one of the goals of the state as the ideals of the state (staatsidee) in the fourth paragraph of the opening of the 1945 Constitution of the Republic of Indonesia, namely "to protect the entire Indonesian nation and all of 
Indonesia's blood", then the current Mineral and Coal Act is part of the government procedure in carrying out economic development through mineral and coal mining where its formation is considered as the state's way of protecting the environment and the constitutional rights of citizens. So that any government policy must fulfill the principles in the Mineral and Coal Act, one of which is Free, Prior, and Informed Consent (FPIC). FPIC is: (OHCHR, 2013: 5)

1. Free implies that there is no coercion, intimidation or manipulation.

2. Prior implies that consent is to be sought sufficiently in advance of any authorization or commencement of activities and respect is shown to time requirements of indigenous consultation/consensus processes.

3. Informed implies that information is provided that covers a range of aspects, including nature, size, pace, reversibility, and scope of any proposed project or activity; the purpose of the project as well as its duration; locality and areas affected; a preliminary assessment of the likely economic, social, cultural and environmental impact, including potential risks; personnel likely to be involved in the execution of the project; and procedures the project may entail. This process may include the option of withholding consent. Consultation and participation are crucial components of a consent process

In addition to the need for open spaces for society in determining their fate and their environment, the Theory of Sustainable Development has also emerged. Sustainable development must be held on three main pillars, namely economic, social and environmental. The three of them are formed to support each other. Henceforth, it can be formulated that sustainable development does not only focus on economic and social development aspects but must also be based on environmental protection. The development of the concept of sustainable development is also included in the fulfillment of basic needs and channeling opportunities to aspire to a better life (Faiz, 2008: 13-15).

\section{CONCLUSIONS}

There has been a change in government policies in the mining sector since the Job Creation Act against the Mineral and Coal Act and the Environmental Protection and Management Act. The Environmental Protection and Management Act and the Mineral and Coal Act, which were only constrained in their implementation, have now had more constraints because of the elimination of the article on community participation;

The purpose of the formation of the Republic of Indonesia is to prosper and protect its people from destruction, so one of the duties of the state is to take responsibility for policymaking including natural resources for the benefit of the entire community. In every decision regarding the policy, FPIC must be implemented and it must be provided to the directly affected communities. Thus, FPIC can be said to be a form of community rights that must be fulfilled by the government as a legal licensor to fulfill the constitutional rights of its citizens. 


\section{RECOMMENDATIONS}

Even though the government wants the economy to improve, the government still has to pay attention to existing regulations, especially in the mining sector, licensing should not be weakened just because it is focused on the economy. If necessary, the government must also have a mining moratorium and focus on fixing damaged environmental problems with reclamation and reducing land disputes, so that existing arrangements can have positive impacts from various sides, or it can be said that there is a balance between the economy and the environment. Some of the abolition of articles from the Environmental Protection and Management Act and the old Mineral and Coal Act must also be returned because these articles are correct, the problem is only in their implementation, more precisely the individuals so that supervision needs to be tightened instead of removing the Article then replacing it with an even more ambiguous Article;

FPIC is rarely communicated in a democratic country like Indonesia, even though this principle is a reflection of a form of certainty for the people's welfare (a form of democracy) so it is necessary to use this meaning in positive law.

Author Contributions: "Conceptualization, H. and A.S.R.; Methodology, E.N.S.; Validation, E.N.S.; Formal Analysis, H.; Investigation, A.S.R.; Resources, H.; Writing-Original Draft, H.; Writing-Review and Editing, R.F.; Supervision, H.; Project Administration, H.; Funding Acquisition, H.; Translation, R.F.

Funding: "This research received no external funding".

Conflicts of Interest: "The authors declare no conflict of interest."

\section{REFERENCES}

Ni'matul Huda. 2012. IImu Negara. Jakarta: Rajawali Pers.

Jimly Asshiddiqie. 2018. Serial Gagasan Konstitusi Sosial Negara Kesejahteraan Sosial Indonesia: Konstitusi Keadilan Sosial. Jakarta: PT Kompas Media Nusantara.

Joni H. 2015. Hukum Lingkungan Kehutanan. Yogyakarta: Pustaka Pelajar. Supriadi. 2006. Hukum Lingkungan Di Indonesia, Sebuah Pengantar. Jakarta: Sinar Grafika.

Kementerian Perencanaan Pembangunan Nasional / Badan Perencanaan Pembangunan Nasional. 2014. Rencana Pembangunan Jangka Menengah Nasional 20152019: Buku I Agenda Pembangunan Nasional. Jakarta.

Konsorsium Pembaruan Agraria. 2019. Catatan Akhir Tahun 2018 Konsorsium Pembaruan Agraria:Masa Depan Reforma Agraria Melampaui Tahun Politik. Jakarta: Januari. 
George W. (Rock) Pring. 1999. Mining, Environment, and Development. A series of papers prepared for the United Nations Conference on Trade and Development (UNCTAD).

M. Hadin Muhjad. 2015. Hukum Lingkungan. Yogyakarta: GENTA Publishing.

A'an Efendi. 2014. Hukum Lingkungan: Instrumen Ekonomik dalam Pengelolaan Lingkungan di Indonesia dan Perbandingannya dengan Beberapa Negara. Bandung: PT. Citra Aditya Bakti.

Nurhayati, Y. 2013. Perdebatan Antara Metode Normatif Dengan Metode Empirik Dalam Penelitian Ilmu Hukum Ditinjau Dari Karakter, Fungsi, dan Tujuan Ilmu Hukum. Jurnal Al Adl, Vol. 5, No. 10.

Nurhayati, Y., Ifrani, M.Y. Said. 2021. Metodologi Normatif dan Empiris Dalam Perspektif Ilmu Hukum. Jurnal Penegakan Hukum Indonesia, Vol. 2, No.1, February 2021.

Nurhayati, Y., 2013. Perdebatan Metode Normatif dengan Metode Empirik Dalam Penelitian Ilmu Hukum Ditinjau Dari Karakter, Fungsi dan Tujuan Ilmu Hukum. Jurnal A/ Adl, Vol. 5, No. 10.

Nurhayati, Y. 2020. Pengantar Ilmu Hukum, Nusa Media, Bandung.

Jimly Asshiddiqie. 2011. Gagasan Negara Hukum Indonesia. Jakarta.

Office of the United Nations High Commissioner for Human Rights (OHCHR). 2013. Free, Prior, and Informed Consent of Indigenous Peoples. Switzerland.

Pan Mohamad Faiz. 2008. Human Right and Constitutional Review: A Basic Foundation of Sustainable Development in Indonesia. Belanda: Delft University of Technology. 